\title{
ANALISIS KINERJA GURU AKUNTANSI BERSETIFIKASI SEKOLAH MENENGAH KEJURUAN (SMK) BISNIS DAN MANAJEMEN
}

\author{
Siswanto \\ Universitas Negeri Yogyakarta \\ siswanto@uny.ac.id
}

\begin{abstract}
Abstrak: Tujuan penelitian ini adalah untuk mengetahui: (1) tingkat kinerja guru, (2) tingkat motivasi guru, dan (3) pengaruh motivasi terhadap kinerja guru. Subjek dalam penelitian ini adalah guru Akuntansi SMK Bisnis dan Manajemen di Daerah Istimewa Yogyakarta yang sudah bersertifikat pendidik. Data yang dapat dikumpulkan sebanyak 46 orang guru. Penelitian ini menggunakan desain survei. Teknik analisi dalam penelitian ini adalag analsis regresi sederhana. Populasinya adalah seluruh guru Akuntansi SMK Bisnis dan Manajemen di Daerah Istimewa Yogyakarta. Sampelnya adalah guru yang sudah bersertifikat pendidik. Sesuai dengan tujuan penelitian, teknik analisis data yang digunakan adalah deskriptif kuantitatif dengan persentase dan analisis regresi sederhana. Hasil Penalitian menunjukkan: (1) Kinerja Guru dinilai dari sudut pandang pedagogik, kepribadian, sosial menunjukkan Kategori Sangat Baik dan kompetensi profesional menunjukkan kategori Baik; (2) tingkat motivasi guru menunjukkan kategori tinggi, (3) terdapat pengaruh motivasi terhadap kinerja guru Akuntansi SMK Bisnis dan Manajemen.
\end{abstract}

Kata kunci: Kinerja Guru, Sertifikasi, Bisnis dan Manajemen, Sekolah Menengah Kejuruan

\section{PERFORMANCE ANALYSIS OF CERTIFIED ACCOUNTING TEACHERS VOCATIONAL HIGH SCHOOLS (VHSS) BUSINESS AND MANAGEMENT}

\begin{abstract}
The purpose of this study was to determine: (1) the level of teacher performance, (2) the level of teacher motivation, and (3) the effect of motivation on teacher performance. The subjects in this study were accounting teachers of SMK Business and Management in the Special Region of Yogyakarta, certified educators. The data that can be collected are 46 teachers. This study used a survey design. The analysis technique in this study is simple regression analysis. The population is all accounting teachers of SMK Business and Management in the Yogyakarta Special Region. The sample is teachers who have been certified educators. In accordance with the research objectives, the data analysis technique used is descriptive quantitative with percentages and simple regression analysis. The results of the research show: (1) Teacher performance is assessed from a pedagogical, personal, social point of view which shows an excellent category and professional competence shows a good category; (2) the level of teacher motivation shows a high category, (3) there is an influence of motivation on the performance of accounting teachers in Business and Management Vocational Schools.
\end{abstract}

Keywords: Teacher Performance, Certification, Business and Management, Vocational Middle School

\section{PENDAHULUAN}

Kapasitas suatu negara ditentukan oleh berbagai aspek salah satunya yang menjadi indikator utama adalah kualitas dari sumber daya manusia, kualitas sumber daya manusia dianggap baik itupun dinilai dari tingkat pendidikannya (Olaleye, 2013). Keberhasilan pendidikan secara umum sangat dipengaruhi oleh faktor internal yaitu kinerja dari guru. Kedudukan guru sangat penting dikarenakan sebagai tumpuan terhadap adanya perubahan khususnya dalam kegiatan belajar mengajar (Mohammad Nadeem et al., 2011). Tinggi rendahnya ukuran kinerja guru salah satu 
dapat diukur melalui kualitas proses belajar mengajar. Dengan demikian kesuksesan proses belajar mengajar dipengaruhi oleh kualitas kinerja guru.

Berdasarkan observasi yang dilakukan di lapangan, mayoritas guru sudah memiliki kinerja yang baik dalam menjalankan kewajibannya dalam rangka menumbuhkembangkan ilmu pengetahuan dan teknologi. Namun, beberapa guru masih kesulitan untuk menjangkau kualitas kinerja sesuai dengan kompetensi yang sesungguhnya. Hal ini akan berdampak terhadap kadar kinerja guru secara masif. Indikator penilaian kinerja guru dapat dibuktikan salah satunya melalui sikap tanggungjawab yang dimiliki dalam mengemban kepercayaan dan tugas dengan baik (Shukla, 2014). Sikap tanggungjawab ini juga termasuk dalam mempersiapkan perangkat pembelajaran sebelum proses belajar mengajar dimulai (Adeyemi, 2010).

Kinerja guru dapat dinilai berdasarkan indikator yang terkandung pada masing-masing bidang keahliannya. Keahlian bidang tersebut meliputi penguasaan ilmu pendidikan, kepribadian, sosial dan pengelolaan pembelajaran. Komponen penilaian kinerja guru diukur melalui keemapat bidang keahlian tersebut. Penilaian tersebut dapat dilihat dari mulai kelengkapan perencanaan dan perangkat pembelajaran, pelaksanaan kegiatan belajar mengajar, serta evaluasi hasil belajar dari peserta didik. (Nasional, 2008) Faktor yang mempengaruhi kinerja seorang dalam bekerja meliputi: ability, capacity, held, incentive, invironment, dan validity. Sementara menurut Mithcell dalam (Nasional, 2008) motivasi dan kemampuan awal adalah indikator utama untuk mengukur kinerja guru.

Rusman (Rusman, 2011) mengemukakan bahwa faktor yang mempengaruhi prestasi kerja bergantung pada motivasinya sedangkan motivasi itu sendiri dipengaruhi kemampuannya awal yang dimiliki (intake). Motivasi kerja sebagian besar dipengaruhi oleh tiga hal yang meliputi faktor sosial, kebutuhan yang perlu dipenuhi dan kondisi fisiknya. Perihal yang akan dibahas dalam penelitian ini adalah belum ditemukannya faktor-faktor determinan kinerja guru. Berdasarkan penelitian (Ismani, Sukanti, 2010) menunjukkan bahwa kinerja guru diukur melalui kemampuan guru dalam melakukan proses penilaian hasil belajar peserta didik kemudian pemahaman guru terkait pedoman penilaian tersebut dan sisanya dalam mengimplementasikan rubrik penilaian dengan keadaan sesungguhnya. Guru dikatakan mampu memberikan penilaian secara tepat apabila memahami rubrik penilaian dan secara cermat mengimplementasikan rubrik tersebut untuk menilai hasil belajar siswa dengan sesungguhnya sehingga pada akhirnya akan mendapatkan penilaian yang holistik baik dari segi pengetahuan, sikap dan keterampilannya. Selain itu pemahaman guru dalam melakukan penilaian juga dapat dijadikan umpan balik guru dalam melakukan perbaikan kualitas mengajarnya.

Berdasarkan data prasurvei dari guru bidang studi Akuntansi SMK Bisnis dan Manajemen, menggambarkan bahwa beberapa guru memiliki kinerja yang masih kurang dikarenakan beberapa guru belum mempunyai motivasi dalam merekomendasikan kenaikan pangkat/golongan tersebut meskipun sudah cukup lama meraih pangkat/golongan tersebut. Selain itu ada temuan terkait guru yang tidak mempersiapkan perangkat pembelajaran. Padahal RPP merupakan salah satu perangkat pembelajaran utama yang harus dipersiapkan untuk menunjang keberhasilan dalam melakukan kegiatan belajar mengajar. Adapun penyusunan kelengkapan perangkat pembelajaran seperti RPP dilakukan terdapat kunjungan yang berkaitan dengan supervisi dan sertifikasi. Beberapa guru berasumsi bahwa sebagian besar guru sudah mengampu mata pelajaran tersebut dalam jangka waktu yang lama sehingga sudah hafal seluk beluk materi ditambah lagi ada beberapa guru yang mendapatkan tugas tambahan sehingga waktu yang dimiliki lebih banyak dialokasikan untuk melaksanakan tugas tersebut. 
Selain itu ada beberapa alasan lain seperti adanya guru yang harus mengampu mata pelajaran lebih dari satu sekolah untuk mencapai 24 jam pelajaran, sehingga banyak waktu yang dialokasikan untuk menjalankan kewajiban tersebut bahkan tidak jarang jarak antar sekolah satu dengan sekolah lain dan kediaman guru tersebut sangat jauh akibatnya kinerja guru jadi rendah. Seseorang tertarik menjadi guru bersumber dari motivasi internalnya. Komponen penting yang menentukan motivasi seseorang dalam bekerja bersumber dari keinginan yang dipenuhi, dorongan untuk mencapai tujuan dan kompensasi yang didapatkan. Berdasarkan teori Maslow, orang bekerja penuh motivasi yang disertai sikap tanggungjawab dikarenakan adanya sejumlah keperluan yang harus dipenuhi. Adapun kebutuhan manusia beragam terdapat lima tingkatan yaitu sebagai berikut: kebutuhan fisik, rasa nyaman, lingkungan sekitar, apresiasi, dan pembuktian diri (Alma, 2006). Perihal dalam penelitian ini adalah belum diketahuinya secara nyata motivasi dari guru bidang studi Akuntansi SMK Bisnis dan Manajemen di Daerah Istimewa Yogyakarta.

Kinerja dimaknai karena suatu sikap yang ditunjukkan seseorang atau organisasi dengan pencapaian kinerjanya (Adeyemi, 2010). Berhubungan dengan kinerja guru, perilaku tersebut dapat digambarkan dalam wujud kegiatan proses pembelajaran, yaitu meliputi kelengkapan menyusun perangkat pembelajaran, mengimplementasikan kegiatan pembelajaran dengan variatif dan mengukur keberhasilan pembelajaran secara umum (Ismail, 2010). Kinerja guru dapat diukur melalui indikator yang sudah tercantum dalam masing- masing bidang keahlian yang meliputi bidang pedagogik, kepribadian, sosial dan profesional (Fernandez, 2013).

Berdasarkan BSNP versi 6.0 11/2008 terkait Indikator Standar Kompetensi Akademik dan Guru yang meliputi: 1)Memahami ciri dari peserta didik; 2) Memegang teguh konsep belajar dan hakikat pembelajaran; 3) Menguraikan kurikulum; 4) Kegiatan pembelajaran; 5) Mengelaborasi kemampuan peserta didik; 6) Dialog dengan peserta didik; 7) Penilaian hasil belajar; 8) Patuh terhadap aturan agama, hukum, dan sosial; 9) Memiliki karakter yang bijaksana; 10) Rajin bekerja, bersikap tanggungjawab, dan rasa hormat kepada guru; 11) Bersikap kompehensif, bertindak objektif serta tidak membeda-bedakan; 12) Berdialog dengan semua perangkat sekolah; 13) Memahami materi dan keilmuan yang menopang mata pelajaran; dan 14) Melakukan tindakan refleksi dengan memperluas kemahiran.

\section{METODE PENELITIAN}

Penelitian ini menggunakan konstruksi survei. Populasinya adalah seluruh guru Akuntansi SMK Bisnis dan Manajemen di Daerah Istimewa Yogyakarta. Sampelnya adalah guru yang sudah bersertifikat pendidik. Data yang dapat dikumpulkan sebanyak 46 orang guru. Instrumen pengumpulan data melalui angket dengan mengacu pada BSNP versi $6.011 / 2008$. Sesuai dengan tujuan penelitian, teknik analisis data menggunakan metode deskriptif kuantitatif dengan persentase dan analisis regresi sederhana. Dalam rangka mengukur kinerja guru digunakan teknik analisis deskriptif kuantitatif dengan persentase dengan kriteria ideal yaitu mean ideal dan standar deviasi ideal. Untuk mendeskripsikan Kinerja Guru dan Motivasi Guru digunakan teknik analisis deskriptif kuantitatif dengan persentase dengan menggunakan mean ideal (Mi) dan standar deviasi ideal (SDi). Dengan demikian untuk mengukur sejauh mana pengaruh motivasi terhadap peningkatan kinerja menggunakan analisis korelasi product moment dan regresi sederhana. 


\section{HASIL DAN PEMBAHASAN}

\section{Kinerja Guru Akuntansi SMK Bisnis dan Manajemen}

Hasil penelitian menunjukkan Kinerja Guru dari Aspek Kompetensi pedagogik menunjukkan skor tertinggi 180. Untuk mengetahui sejauh mana tendensi kinerja guru ditinjau dari aspek kompetensi pedagogik, dapat disusun tabel 1 berikut ini.

Tabel. Kinerja Guru dari aspek Kompetensi Pedagogik

\begin{tabular}{llcc}
\hline Kategori & Rentang & Jumlah & Persentase \\
\hline Sangat Baik & $>146,25$ & 29 & 63,04 \\
Baik & $112,5-146,25$ & 17 & 36,96 \\
Cukup Baik & $78,75-112,49$ & 0 & 0,00 \\
\hline Jumlah & & 46 & 100 \\
\hline
\end{tabular}

Bersumber tabel 1 tersebut menunjukkan bahwa Kinerja Guru dari Aspek Kompetensi Pedagogik pada kategori sangat baik dengan nilai 63,04\% dengan frekuensi sebanyak 29 responden. Kecenderungan Kinerja Guru bidang penguasaan ilmu pendidikan yang berada pada posisi sangat baik menggambarkan bahwa Guru telah mampu mengelaborasi kurikulum, mengimplementasikan pembelajaran, memanfaatkan perkembangan teknologi untuk pembelajaran serta melengkapi fasilitas untuk mengimplementasikan berbagai potensi yang dimiliki (Ismani, Sukanti, 2010). Kinerja Guru dari Aspek Kompetensi Kepribadian menunjukkan skor tertinggi 72 dari skor tertinggi yang mungkin dicapai sebesar 72, dan skor terendah yang dicapai sebesar 52 dari skor terendah yang mungkin dicapai sebesar 18. Untuk mengetahui kecenderungan tingkat kinerja guru ditinjau dari aspek kompetensi Kepribadian, dapat disusun tabel 2 berikut ini.

Tabel 2. Kinerja Guru dari aspek Kompetensi Kepribadian

\begin{tabular}{llcc}
\hline Kategori & Rentang & Jumlah & Persentase \\
\hline Sangat Baik & $>58,5$ & 36 & 78,26 \\
Baik & $45-58,5$ & 10 & 21,74 \\
Cukup Baik & $31,25-44,9$ & 0 & 0,00 \\
\hline Jumlah & & 46 & 100 \\
\hline
\end{tabular}

Dari hasil analisis data menggambarkan bahwa kecenderungan Kompetensi kepribadian Guru mendeskripsikan bahwa kategori Sangat Baik, dengan kategori kompetensi kepribadian yang sangat baik dipastikan guru dapat memiliki kemampuan untuk menjadi contoh dalam pelaksanaan pembelajaran maupun di luar kegiatan pembelajaran (Ismail, 2010). Selain itu dapat dimaknai bahwa guru telah dapat mendemostrasikan sebagai pribadi yang bijaksana dan berwibawa serta mampu membawa dirinya menjadi pribadi yang dapat dijadikan contoh yang baik bagi peserta didik (Nasional, 2008).

Kinerja Guru dari Aspek Kompentensi Sosial menunjukkan skor tertinggi 24 dan skor terendah yang dicapai sebesar 16, Mean sebesar 21,30 median 21,50 modus 24 dan standar deviasi 2,00. Untuk mengetahui sejauhmana tendensi kinerja guru ditinjau dari aspek kompetensi Sosial dapat disusun tabel 3 berikut ini. 
Tabel 3. Kinerja Guru dari aspek Kompetensi Sosial

\begin{tabular}{llcc}
\hline Kategori & Rentang & Jumlah & Persentase \\
\hline Sangat Baik & $>19,5$ & 31 & 67,39 \\
Baik & $15-19,5$ & 15 & 32,61 \\
Cukup & $10,5-14,9$ & 0 & 0,00 \\
Rendah & $<10,5$ & 0 & 0,00 \\
\hline Jumlah & & 46 & 100
\end{tabular}

Hasil kecencerungan Kompentensi Sosial dari guru menggambarkan bahwa hasil Sangat Baik, hal ini dapar diartikan bahwa guru memiliki keterampilan berkomunikasi secara baik dan empatik dengan peserta didik, orang tua peserta didik, sesama pendidik, tenaga kependidikan dan masyarakat (Ismail, 2010). Guru telah berperan terhadap pengembangan dan perluasan pendidikan di sekolah dan masyarakat. Selain itu juga dapat di pastikan guru memiliki kedudukan terhadap perluasaan pendidikan diberbagai tingkatan baik lokal maupun secara globa, selain itu juga adanya pemanfaatan teknologi informasi dan komunikasi untuk berkomunikasi dan pengembangan diri (Nasional, 2008). Profesionalisme guru sebagai suatu keahlian yang memiliki kedudukan yang fundamental, guru yang memiliki profesionalisme yang tinggi dapat menginspirasi peserta didik dengan berbagai wawasan dan pengalaman sehingga mampu meningkatkan kualitas dan keberhasilan pembelajaran yang sudah berlangsung (Ismail, 2010).

Tabel 4. Kinerja Guru dari aspek Kompetensi Profesional

\begin{tabular}{llcc}
\hline Kategori & Rentang & Jumlah & Persentase \\
\hline Sangat Baik & $>29,75$ & 10 & 21,74 \\
Baik & $22,5-29,75$ & 27 & 58,70 \\
Cukup & $15,75-22,49$ & 8 & 17,39 \\
Rendah & $<15,75$ & 1 & 2,17 \\
\hline Jumlah & & 46 & 100 \\
\hline
\end{tabular}

Dari tabel 4 diatas dapat di ketahui jika Kinerja Guru dari aspek Kompetensi Profesional menunjukkan kategori Baik, hal ini menggambarkan kemampuan penguasaan substansi bidang studi dan metodologi keilmuannya serta komponen dan muatan dalam kurikulum dengan proporsional serta dapat mengintegrasikan materi bidang studi dengan muatan kurikulum sehingga hasil akhirnya mampu meningkatkan kualitas pembelajaran (Ismail, 2010).

\section{Motivasi Guru Akuntansi SMK Bisnis dan Manajmen}

Hasil penelitian yang mengungkap Motivasi Guru Akuntansi menunjukkan skor tertinggi 100 dari skor tertinggi yang mungkin dicapai sebesar 100, dan skor terendah yang dicapai sebesar 64 dari skor terendah yang mungkin dicapai sebesar 25. Mean sebesar 80,96 median 79 modus 75 dan standar deviasi 8,00. Untuk mengetahui kecenderungan tingkat motivasi guru dapat disusun tabel 5 berikut ini. 
Tabel 5. Motivasi Guru Akuntansi SMK Bisnis dan Manajemen

\begin{tabular}{llcc}
\hline Kategori & Rentang & Jumlah & Persentase \\
\hline Sangat Baik & $>81,25$ & 21 & 45,65 \\
Baik & $62,5-81,25$ & 25 & 54,35 \\
Cukup & $43,75-62,49$ & 0 & 0,00 \\
\hline Jumlah & & 46 & 100 \\
\hline
\end{tabular}

Tabel 5 menunjukkan sebanyak 45,65\% tingkat motivasi sangat tinggi, 54,35\% tinggi, tidak ada yang kategori cukup dan rendah. Berdasarkan hasil penelitian ini dapat disimpulkan bahwa sebagian besar (54,35\%) Tingkat motivasi Guru Akuntansi SMK Bisnis dan Manajemen di DIY tinggi.

\section{Pengaruh Motivasi terhadap Kinerja Guru Akuntansi SMK Bisnis dan Manajemen}

Berdasarkan perhitungan statistik menunjukkan hubungan antara Motivasi dengan Kinerja Guru sebesar 0,481 dan koefisien determinasi sebesar 0,214 yang berarti 21,40\% Kinerja Guru dipengaruhi Motivasi Guru. Hasil penelitian ini tidak sesuai dengan pendapat dari (Rusman, 2011) yang menyatakan bahwa prestasi kerja itu sendiri untuk $80-90 \%$ tergantung motivasinya untuk bekerja. Motivasi adalah dorongan untuk bertindak sedangkan motif adalah kemauan. Motivasi seseorang tergantung pada dorongan (Mangkunagara, 2001). Motif yang besar merupakan penentu perilaku seseorang, namun apabila motif yang dimiliki akan melemah bila telah mencapai titik kepuasan. Jadi kekuatan motif ini akan berganti karena terpenuhinya kebutuhan. Maslow menjelaskan bahwa jenjang kebutuhan manusia dapat digunakan untuk memprediksi dan mengestimasikan motivasi (Alma, 2006). Motivasi didasarkan pada dua asumsi yaitu kebutuhan seseorang bergantung pada kemampuan awal yang dimiliki, dan kebutuhan merupakan skala preferensinya (Mangkunagara, 2001). Teori kebutuhan Maslow mengemukakan bahwa motivasi seseorang dalam bekerja karena adanya keinginan untuk meemenuhi sejumlah kebutuhan yang dimiliki.

Persamaan garis regresi $Y=1,436+0,481$ b yang berarti jika Motivasi Guru ditingkatkan satu satuan maka Kinerja Guru akan meningkat 0,481. Pimpinan dapat mendorong kinerja guru dengan memetakan kebutuhan apa yang dapat meningkatkan kinerja guru. Berdasarkan hasil uji statistik guru menganggap kebutuhan di masa depan belum terpenuhi secara utuh, hal ini dapat dimaknai karena guru yang menjadi sampel tidak semua dalam kategori penerima tunjangan pensiun. Meskipun Kinerja Guru sudah tergolong bagus, namun masih perlu diperhatikan terkait tindak lanjut terkait implementasi dalam pembelajaran yaitu sebaiknya guru memberikan perbaikan terkait kritik dan saran dan menjadikan umpan balik untuk mengembangkan proses pembelajaran misalnya dengan pengayaan atau remedial. Selain itu dari pihak pemangku kepentingan perlu mencari faktor determinan yang mempengaruhi Kinerja Guru sehingga kebijakan yang dirumuskan sesuai dengan kebutuhan di lapangan contohnya penilaian terkait pemberian tunjangan profesi guru memiliki hubungan positif dengan peningkatan kinerja guru (Nasional, 2008).

Hal ini diperkuat dengan penelitian yang dilakukan oleh (Ardiana, 2017) bahwa ada pengaruh motivasi kerja terhadap kinerja guru akuntansi SMK disebabkan tumbuhnya rasa tanggung jawab dan pemahaman tujuan atau makna dari kerja yang selama ini dijalani, sehingga kinerja guru akuntansi semakin meningkat di sekolah menengah kejuruan (SMK). Lebih lanjut (Riyadi \& Mulyapradana, 2017) Apabila pekerja mempunyai motivasi yang tinggi untuk mencapai tujuan pribadinya, maka mereka harus meningkatkan kinerja. Meningkatnya kinerja pekerja akan 
meningkat pula kinerja organisasi. Dengan demikian, meningkatkannya motivasi pekerja akan meningkatkan kinerja individu, kelompok, maupun organisasi sehingga dapat mencapi target organisasi yang telah ditetapkan. Motivasi berhubungan dengan upaya - upaya memenuhi kebutuhan oleh karena itu semakin besar kebutuhan, maka semakin besar pula dorongan dalam diri seseorang untuk mau melakukan sesuatu. Karena itu peran motivasi untuk menunjang keberhasilan sangat penting. Inti mempimpin adalah bagaimana mampu untuk memotivasi. Tantangan bagi pimpinan adalah bagaimana memotivasi anggotanya (Supartha, 2016).

\section{KESIMPULAN}

Berdasarkan hasil penelitian kinerja guru ditinjau dari bidang pedagogik menunjukkan $63,04 \%$. Apabila dilihat dari bidang kepribadian menunjukkan 78,26\% tingkat kinerjanya sangat baik. Apabila dilihat dari bidang Sosial menunjukkan $67,39 \%$ tingkat kinerjanya sangat baik, 32,61\% baik serta dari bidang profesional menunjukkan 21,74\% tingkat kinerjanya sangat baik, 58,70\% baik, $17,39 \%$ cukup dan 2,17\% rendah. Berdasarkan uji statistik motivasi Guru bidang studi Akuntansi memperoleh nilai 80,96\% dengan keterangan sebanyak 45,65\% tingkat motivasi sangat tinggi, 54,35\% tinggi. Koefisien korelasi antara Motivasi Guru dengan Kinerja Guru sebesar 0,481 dan koefisien determinasi sebesar 0,214. Faktor determinan yang mempengaruhi Kinerja Guru adalah Motivasi Guru yang meliputi adanya kebutuhan yang dirasakan oleh guru. Jika Motivasi Guru ditingkatkan satu satuan maka Kinerja Guru akan meningkat sebesar 0,418.

\section{DAFTAR PUSTAKA}

Adeyemi, T. O. (2010). Principals' leadership styles and teachers' job performance in senior secondary schools in Ondo State, Nigeria. Journal of Education, 2(July), 83-91. http://maxwellsci.com/print/crjet/v3-84-92.pdf

Alma, B. (2006). Kewirausahaan. Bandung: Alfabeta.

Ardiana, T. E. (2017). Pengaruh Motivasi Kerja Guru Terhadap Kinerja Guru Akuntansi Smk Di Kota Madiun. Jurnal Akuntansi Dan Pajak, 17(02), 14-23. https://doi.org/10.29040/jap.v17i02.11

Fernandez, R. (2013). Teachers' Competence And Learners' Performance In The Alternative Learning System Towards An Enriched Instructional Program. International Journal of Information Technology and Business Management, $22(1), \quad 34$. https://doi.org/10.13140/RG.2.2.26402.15042

Ismail, M. I. (2010). Kinerja Dan Kompetensi Guru Dalam Pembelajaran. Lentera Pendidikan : Jurnal Ilmu Tarbiyah Dan Keguruan, 13(1), 44-63. https://doi.org/10.24252/lp.2010v13n1a4

Ismani, Sukanti, A. W. (2010). Analisis Kinerja Guru Akuntansi Dalam Melaksanakan Evaluasi Pembelajaran. April, 1-57.

Mangkunagara, A. P. (2001). Manajemen Sumber Daya Manusia Perusahaan. PT. RemajaRosdakarya Aditama.

Mohammad Nadeem, Musarrat Shaheen Rana, Abdul Hameed Lone, Saira Maqbool, Khansa Naz, \& Akhtar Ali. (2011). Teacher's Competencies and Factors Affecting the Performance of Female Teachers in Bahawalpur (Southern Punjab) Pakistan . International Journal of Business and Social Science, 2(19), 217-222.

Nasional, D. P. (2008). Penilaian Kinerja Guru. Direktorat Tenaga Kependidikan Direktorat Jendral 
Jurnal Ekonomi \& Pendidikan, 18(1), 2021

Peningkatan Mutu Pendidik dan Tenaga Kependidikan.

Olaleye, F. O. (2013). Improving Teacher Performance Competency Through Effective Human Resource Practices in Ekiti State Secondary Schools. Singaporean Journal of Business , Economics and Management Studies, 1(11), 125-132. https://doi.org/10.12816/0003819

Riyadi, S., \& Mulyapradana, A. (2017). Pengaruh Motivasi Kerja Terhadap Kinerja Guru Radhatul Atfal di Kota Pekalongan. Jurnal Litbang Kota Pekalongan, 13, 106-117.

Rusman. (2011). Model-model pembelajaran : mengembangkan profesionalisme guru (1st ed.). Rajawali Pers.

Shukla, S. (2014). Teaching Competency, Professional Commitment and Job Satisfaction-A Study of Primary School Teachers. IOSR Journal of Research \& Method in Education (IOSRJRME), 4(3), 44-64. https://doi.org/10.9790/7388-04324464

Supartha, W. G. (2016). PENGARUH GAYA KEPEMIMPINAN DAN MOTIVASI KERJA TERHADAP KINERJA GURU. Jurnal Ekonomi Dan Bisnis, 3, 429-454. 